\title{
Influence of Recycled Concrete Aggregates and Slag on the Performance of Pervious Concrete
}

\author{
Hilal El-Hassan ${ }^{1}$, Peiman Kianmehr ${ }^{2}$ \\ ${ }^{1}$ UAE University, Department of Civil and Environmental Engineering \\ Al Ain, United Arab Emirates \\ helhassan@uaeu.ac.ae \\ ${ }^{2}$ American University in Dubai \\ Dubai, United Arab Emirates \\ pkianmehr@aud.edu
}

\begin{abstract}
This paper examines the properties of pervious concrete made with recycled concrete aggregates (RCA) and slag. RCA replaced natural aggregates at varying percentages of 0,50 , and $100 \%$, while slag replaced $50 \%$ of cement. Pervious concrete mixes were prepared with porosities of 10 and $20 \%$. Slump, hardened density, total void content, compressive strength, and flexural strength were assessed to characterize the performance. Results showed that RCA replacement led to an increase in void content and a decrease in slump and hardened density. The strengths decreased owing to a weak RCA particle and a weak interface between the RCA and new cement paste. Yet, the incorporation of slag could enhance the slump, hardened density, compressive strength, and flexural strength, while reducing the void content. Experimental findings highlight the ability to employ pervious concrete made with $100 \%$ RCA and 50\% slag in pavement applications.
\end{abstract}

Keywords: Pervious concrete; recycled concrete aggregates; slag; performance evaluation.

\section{Introduction}

Management of construction and demolition wastes (CDW) is a globally concerning matter. The demolition, construction and renovation of existing structures generates excessive debris and waste, which stretches the limited landfill capacity and induces major economic losses [1]. In the United Kingdom, for instance, some 20 million tons of waste and debris are disposed of in landfills annually, of which more than $30 \%$ are concrete waste [2]. Scientists have proposed recycling these wastes as a sustainable solution to reduce the consumption of storage sites and natural resources [3, 4]. As a result, a recycled concrete aggregate (RCA) was produced, comprising 65-70\% original aggregate and 30-35\% original cement paste, by volume [5]. Yet, its use in structural concrete applications has been limited due to a reduction in mechanical and durability performance [6-8]. As a result, its use has been restricted to non-structural or pavement concrete applications.

Pervious concrete has been recommended by the U.S. Environmental Protection Agency (EPA) as a sustainable construction material [9]. This recommendation is attributed to its many advantages, including natural treatment of water, elimination of storm water collection systems, and restoration of ground water aquifers. In addition, it improves the quality of the pavement in terms of skid resistance and tire-pavement noise [10-12]. Typical pervious concrete has a density, permeability, porosity, compressive strength, and flexural strength in the respective ranges of $1600-2000 \mathrm{~kg} / \mathrm{m}^{3}, 1.3-12.2$ $\mathrm{mm} / \mathrm{s}, 10-35 \%, 3.5-28 \mathrm{MPa}$, and 1-3.8 MPa [13]. For this reason, it may be utilized as a sustainable construction material for walkways, light traffic roads, sidewalks, shoulders, and parking areas [10, 14].

Recent work has incorporated RCA in pervious concrete mixtures. Zaetang, et al. [15] and Kumar [16] reported an increase in compressive strength and abrasion resistance when natural aggregates were replaced by $20 \%$ RCA, owing to increased roughness of RCA and enhanced bond properties between RCA and new cement paste. However, a significant reduction in performance was noted with more than $20 \%$ RCA replacement. Clearly, it is possible to replace natural aggregates by RCA for pervious concrete applications; yet, this replacement is limited to $20 \%$.

In an attempt to maximize the RCA replacement percentage, this paper investigates the effect of slag incorporation on the rheological, physical, and mechanical performance of pervious concrete made with RCA. A total of 12 mixes were designed in two groups with design porosities of 10 and $20 \%$. RCA replacement percentages were varied among 0,50 , and 
$100 \%$. Cement was partially replaced by ground granulated blast furnace slag (or simply slag) as a means to reduce the carbon footprint of the proposed mixtures and enhance the performance. So-produced pervious concrete mixtures were assessed for slump, hardened density, void content, compressive strength, and flexural strength.

\section{Materials}

\subsection{Materials Properties}

Ordinary Portland cement (OPC - Type I) and slag served as the binding materials in the pervious concrete. Table 1 summarizes their chemical composition as obtained by X-ray fluorescence (XRF). The specific gravity, unit weight, and surface area of cement and slag were 3.14 and $2.9,1440$ and $1209 \mathrm{~kg} / \mathrm{m}^{3}$, and 3670 and $4550 \mathrm{~cm}^{2} / \mathrm{g}$, respectively. Their particle size distributions are presented in Fig. 1. A single size natural aggregate (NA), in the form of crushed stone, was used with a bulk density of $1635 \mathrm{~kg} / \mathrm{m}^{3}$, water absorption of $0.22 \%$, and specific gravity of 2.82 . In contrast, recycled concrete aggregates (RCA) were sourced from construction and demolition waste by a local recycling facility with bulk density of $1563 \mathrm{~kg} / \mathrm{m}^{3}$, water absorption of $6.63 \%$, and specific gravity of 2.63. Sieve analysis was employed to determine the particle size distribution, shown in Fig. 1. While both aggregates have the same nominal maximum size (NMS) of $20 \mathrm{~mm}$ and fineness modulus of 2.50, RCA has a lower density and specific gravity and higher absorption capacity.

Table 1: Chemical composition of cement and slag by XRF.

\begin{tabular}{|l|l|l|l|l|l|l|l|l|}
\hline Component & $\mathrm{SiO}_{2}$ & $\mathrm{CaO}$ & $\mathrm{Al}_{2} \mathrm{O}_{3}$ & $\mathrm{Fe}_{2} \mathrm{O}_{3}$ & $\mathrm{MgO}$ & $\mathrm{NaO}$ & $\mathrm{SO}_{3}$ & LOI \\
\hline Cement (\%) & 19.9 & 63.2 & 4.9 & 2.3 & 2.5 & 0.8 & 3.8 & 2.6 \\
\hline Slag (\%) & 35.4 & 42.1 & 10.6 & 0.4 & 8.1 & - & 0.3 & 3.1 \\
\hline
\end{tabular}

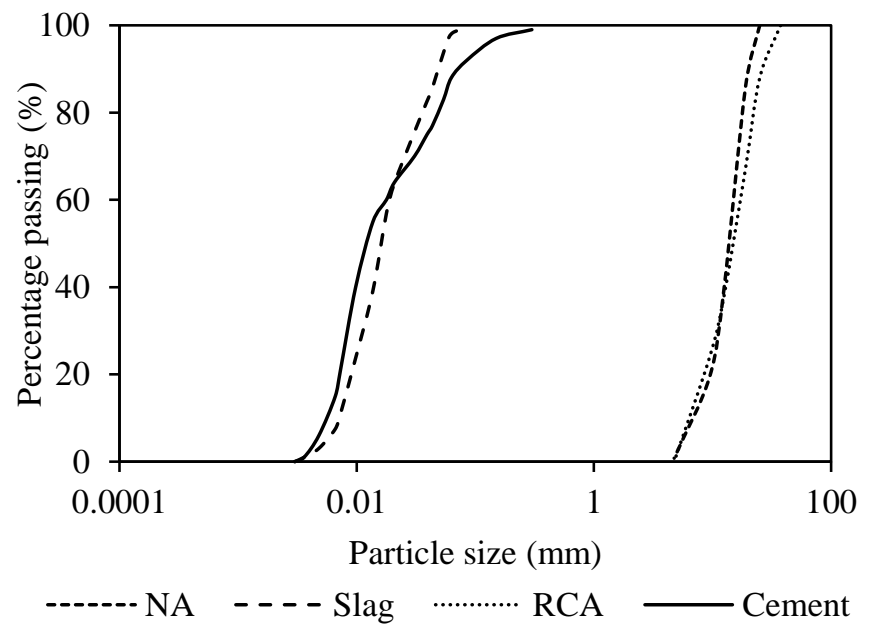

Fig. 1: Particle size distribution of slag, cement, and aggregates.

\subsection{Pervious Concrete Mixture Proportioning}

ACI 522R-10 [17] was employed to design the pervious concrete mixture proportions. Table 2 summarizes the obtained mixtures. Pervious concrete mixes are labeled as $\mathrm{Sx} / \mathrm{Ry} / \mathrm{Pz}$, where $\mathrm{S}, \mathrm{R}$, and $\mathrm{P}$ are respective percentages of slag replacement, RCA replacement, and design porosity. For example, S50/R50/P20 represents a pervious concrete mix made with 50\% slag, 50\% RCA replacement, and a $20 \%$ porosity. The twelve mixes were designed with a fixed waterto-cement ratio $(\mathrm{w} / \mathrm{c})$ of 0.4 . The aim was to examine the influence of RCA replacement $(0,50$, and $100 \%)$ and slag incorporation ( 0 and $50 \%$ ) on the performance of pervious concrete.

\subsection{Pervious Concrete Sample Preparation}

Pervious concrete samples were prepared and cast under ambient laboratory conditions at a temperature of $24 \pm 2^{\circ} \mathrm{C}$ and relative humidity of $50 \pm 5 \%$. First, the slag, cement, and saturated surface dry (SSD) aggregates, were mixed in a pan mixer for 3 minutes. Then, water was incorporated into the dry components and further mixed for 3 minutes to 
ensure a homogeneous mixture. The freshly-mixed pervious concrete batch was cast in $150 \mathrm{x} 300 \mathrm{~mm}$ cylinders and $150 \mathrm{x}$ $150 \times 450 \mathrm{~mm}$ prisms in two layers and placed on a vibration table for 10 seconds to ensure proper compaction. Samples were removed from the table and covered with a plastic sheet for 24 hours to prevent water evaporation. Specimens were then demolded and moist-cured in a water tank at $23 \pm 1^{\circ} \mathrm{C}$ until testing.

Table 2: Pervious concrete mixture proportions.

\begin{tabular}{|l|l|l|l|l|l|l|l|}
\hline $\begin{array}{l}\text { Mix } \\
\text { No. }\end{array}$ & $\begin{array}{l}\text { Mixture } \\
\text { Designation }\end{array}$ & $\begin{array}{l}\text { Slag } \\
\left(\mathrm{kg} / \mathrm{m}^{3}\right)\end{array}$ & $\begin{array}{l}\text { Cement } \\
\left(\mathrm{kg} / \mathrm{m}^{3}\right)\end{array}$ & $\begin{array}{l}\text { NA } \\
\left(\mathrm{kg} / \mathrm{m}^{3}\right)\end{array}$ & $\begin{array}{l}\mathrm{RCA} \\
\left(\mathrm{kg} / \mathrm{m}^{3}\right)\end{array}$ & $\begin{array}{l}\text { Water } \\
\left(\mathrm{kg} / \mathrm{m}^{3}\right)\end{array}$ & $\begin{array}{l}\text { Design } \\
\text { Porosity }(\%)\end{array}$ \\
\hline 1 & S0/R0/P10 & 0 & 580 & 1404 & 0 & 232 & 10 \\
\hline 2 & S0/R50/P10 & 0 & 540 & 683 & 683 & 216 & 10 \\
\hline 3 & S0/R100/P10 & 0 & 500 & 0 & 1325 & 200 & 10 \\
\hline 4 & S50/R0/P10 & 290 & 290 & 1468 & 0 & 232 & 10 \\
\hline 5 & S50/R50/P10 & 270 & 270 & 714 & 714 & 216 & 10 \\
\hline 6 & S50/R100/P10 & 250 & 250 & 0 & 1386 & 200 & 10 \\
\hline 7 & S0/R0/P20 & 0 & 384 & 1395 & 0 & 153 & 20 \\
\hline 8 & S0/R50/P20 & 0 & 355 & 675 & 675 & 142 & 20 \\
\hline 9 & S0/R100/P20 & 0 & 326 & 0 & 1304 & 130 & 20 \\
\hline 10 & S50/R0/P20 & 192 & 192 & 1395 & 0 & 153 & 20 \\
\hline 11 & S50/R50/P20 & 178 & 178 & 675 & 675 & & 20 \\
\hline 12 & S50/R100/P20 & 163 & 163 & 0 & 1304 & 130 & 20 \\
\hline
\end{tabular}

\section{Experimental Methods}

\subsection{Slump, hardened density, and void content}

The effects of slag and RCA replacements on the workability and rheological properties of fresh pervious concrete was assessed by the slump, following the procedure of ASTM C143 [18]. Hardened concrete density was determined at the age of 28 days, as per ASTM C1754 [19]. The total void content (ratio, \%) was compared to the design porosity of pervious concrete. It was determined using Eq. (1) [20]. To obtain an average of test results, three samples were tested for each experiment.

$$
\text { Void content }(\%)=\left(1-\left(\frac{\text { Saturated Weight }(\mathrm{kg}) \text { - Submerged Weight }(\mathrm{kg})}{\text { Sample Volume }\left(\mathrm{m}^{3}\right) \cdot \text { Density of Water }\left(\mathrm{kg} / \mathrm{m}^{3}\right)}\right)\right) \times 100
$$

\subsection{Compressive and Flexural Strengths}

The mechanical performance of pervious concrete was characterized by the 28-day compressive and flexural strengths. They were determined in accordance with ASTM C39 [21] and ASTM C78 [22], respectively. For each experiment, three replicate samples per mix were tested to obtain an average.

\section{Results and Discussions}

\subsection{Slump, Void Content and Density}

The workability of fresh pervious concrete mixes is characterized by the slump, as shown in Table 3 . Increasing the RCA replacement led to a lower slump. In fact, with $10 \%$ porosity and $0 \%$ slag (S0/R0/P10, S0/R50, P10, and S0/R100/P10), the slump decreased from 70 to $59 \mathrm{~mm}$, representing a $16 \%$ reduction, when the RCA replacement was increased from 0 to $50 \%$. An additional $15 \%$ decrease in slump was observed when $100 \%$ RCA was used. Similar results were noted for $20 \%$ porosity mixes. These reductions are owed to the change in particle shape and nature of aggregates when RCA replaced NA. Furthermore, slag incorporation resulted in an increase in slump. For 10 and $20 \%$ porosity mixes, the increase was on average 18 and $21 \%$, respectively. The smooth surface texture of slag created a more workable concrete with higher slump [23]. 
Also, the effect of increasing porosity was examined. Lesser cement paste used in $20 \%$ porosity mixes provided less lubrication to the aggregates, causing a decrease in the slump.

Table 3 also presents the total void content (\%) of hardened pervious concrete mixes. A slight increase in void content was noted upon the replacement of NA by RCA, as more entrapped air was introduced into the concrete. This is possibly due to the more angular shape and rougher surface texture of RCA and/or the existing less solid mortar on the RCA. In contrast, the replacement of cement by $50 \%$ slag resulted in lesser voids. It is believed that the chemical reaction between slag and developed calcium hydroxide created a densified binding matrix and reduced the void content [24].

The 28-day hardened density of pervious concrete mixes is displayed in Table 3. Results ranged between 1625 to $1984 \mathrm{~kg} / \mathrm{m}^{3}$, which are typical for pervious concrete [13]. Clearly, higher replacement percentages of NA by RCA led to a reduction in density. Given the lower bulk density of RCA, lighter pervious concrete was produced with RCA replacement. Nevertheless, the angular shape and rough surface texture of RCA may have introduced more entrapped air, thus, lowering the hardened density. Additionally, the incorporation of slag resulted in higher density with lesser voids. This highlights the inversely proportional relationship between density and void content, whereby the former decreases as the latter increases.

Table 3: Slump, void content, and hardened density of pervious concrete mixes.

\begin{tabular}{|l|l|l|l|l|}
\hline $\begin{array}{l}\text { Mix } \\
\text { No. }\end{array}$ & $\begin{array}{l}\text { Mixture } \\
\text { Designation }\end{array}$ & $\begin{array}{l}\text { Slump } \\
(\mathrm{mm})\end{array}$ & $\begin{array}{l}\text { Void } \\
\text { Content }(\%)\end{array}$ & $\begin{array}{l}\text { Hardened } \\
\text { Density }\left(\mathrm{kg} / \mathrm{m}^{3}\right)\end{array}$ \\
\hline 1 & S0/R0/P10 & $70 \pm 4$ & $10.1 \pm 0.8$ & $1972.8 \pm 42$ \\
\hline 2 & S0/R50/P10 & $59 \pm 3$ & $11.5 \pm 0.9$ & $1850.2 \pm 31$ \\
\hline 3 & S0/R100/P10 & $50 \pm 3$ & $14.0 \pm 0.9$ & $1808.1 \pm 25$ \\
\hline 4 & S50/R0/P10 & $81 \pm 5$ & $9.5 \pm 0.7$ & $1983.6 \pm 44$ \\
\hline 5 & S50/R50/P10 & $69 \pm 4$ & $11.3 \pm 0.9$ & $1868.1 \pm 36$ \\
\hline 6 & S50/R100/P10 & $60 \pm 3$ & $12.0 \pm 0.9$ & $1836.9 \pm 30$ \\
\hline 7 & S0/R0/P20 & $55 \pm 3$ & $18.0 \pm 1.1$ & $1742.4 \pm 28$ \\
\hline 8 & S0/R50/P20 & $46 \pm 2$ & $21.2 \pm 1.2$ & $1657.6 \pm 22$ \\
\hline 9 & S0/R100/P20 & $35 \pm 2$ & $22.0 \pm 1.2$ & $1624.5 \pm 20$ \\
\hline 10 & S50/R0/P20 & $65 \pm 3$ & $16.2 \pm 1.0$ & $1785.6 \pm 30$ \\
\hline 11 & S50/R50/P20 & $53 \pm 3$ & $20.5 \pm 1.1$ & $1710.5 \pm 27$ \\
\hline 12 & S50/R100/P20 & $45 \pm 2$ & $21.0 \pm 1.1$ & $1692.0 \pm 24$ \\
\hline
\end{tabular}

\subsection{Compressive Strength}

Fig. 2 displays the compressive strength of pervious concretes made with different proportions of RCA and slag. Higher replacement percentages of NA by RCA resulted in lower compressive strength. For concretes with $10 \%$ design porosity and no slag (S0/P10), RCA replacement of 50 and 100\% led to 75 and $87 \%$ reduction in compressive strength, respectively. Similar results are noted for slag-free pervious concretes with $20 \%$ design porosity, with 72 and $83 \%$ reductions in compressive strength. This is attributed to a weak bond between the adhered mortar layer in the RCA and the new cement paste [25]. Also, it is possible that the low bulk density and porous nature of RCA may have contributed to the inferior mechanical property [26]. These results are in good agreement with hardened density and void content results, whereby higher RCA replacement percentages created more voids and lowered the density, leading to a reduced compressive strength.

Upon the addition of $50 \%$ slag, the $10 \%$-porosity concrete sample with natural aggregates (S50/R0/P10) reached $37 \mathrm{MPa}, 28 \%$ higher than its cement-based equivalent (S0/R0/P10). As noted earlier, this is attributed to the slag/calcium hydroxide reaction that reduced the void content, densified the cementitious matrix, and enhanced the concrete strength [24]. In addition, the replacement of cement by 50\% slag in 50 and 100\% RCA pervious concretes resulted in 195 and 
$142 \%$ higher compressive strength compared to their cement-based counterparts. Clearly, the impact of slag was much more significant in weaker mixes incorporating RCA. Similarly, 23, 138, and 155\% increases in strength can be noted when 50\% slag replaced cement in 20\%-porosity mixes with 0,50, and 100\% RCA, respectively.

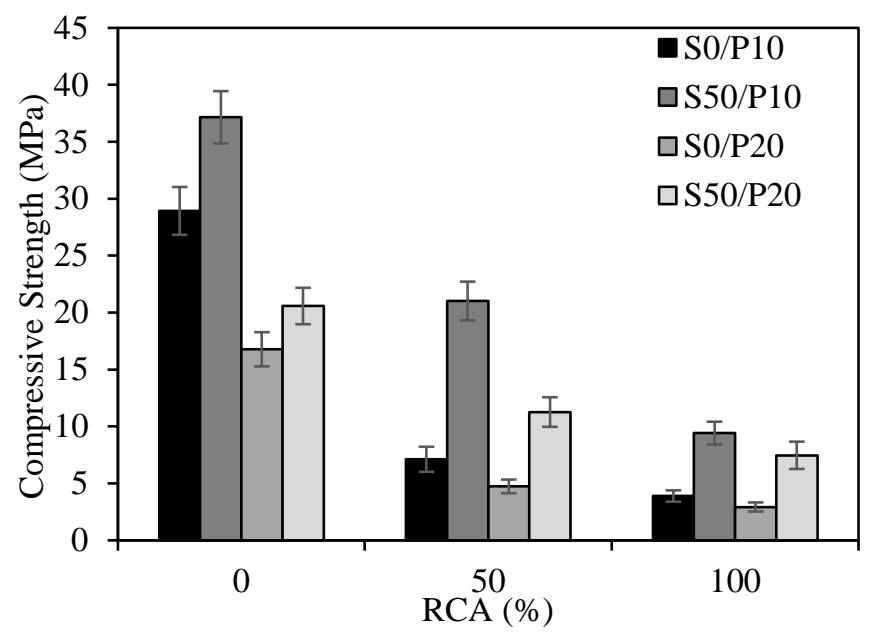

Fig. 2: Compressive strength of pervious concrete mixes.

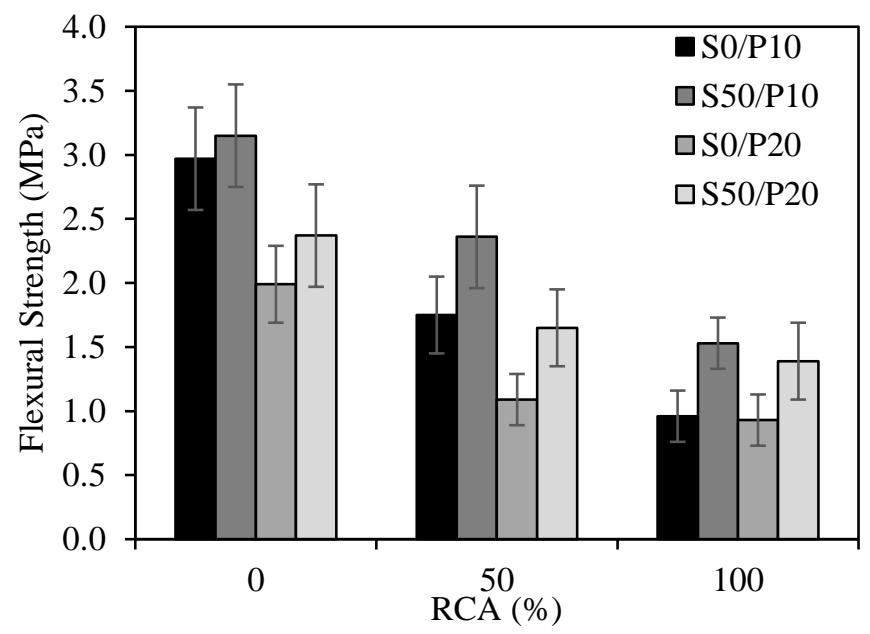

Fig. 3: Flexural strength of pervious concrete mixes.

\subsection{Flexural Strength}

The 28-day flexural strength of pervious concrete samples is shown in Fig. 3. The flexural strength follows a similar trend to that of the compressive strength. Values ranged between 0.93 and $3.15 \mathrm{MPa}$. Irrespective of the mix design, a decrease in flexural strength was observed with replacement of NA by RCA. For 10 and 20\% porosity concrete mixes made without slag, the average loss in strength was 43 and $61 \%$ for 50 and 100\% RCA replacement, respectively. The addition of slag improved the performance. In fact, the before-mentioned losses were reduced to an average 22 and $45 \%$. It seems that the addition of slag densified the cementitious matrix, rendering it less susceptible to losses due to RCA replacement.

For concrete pavement applications, it has been recommended that the compressive and flexural strengths be in the range of 3.5-28 MPa and 1-3 MPa, respectively [13]. The results presented herein show that it is possible to replace NA by $100 \%$ RCA in the production of pervious concrete with $50 \%$ cement replacement by slag and a porosity of $10-20 \%$. This work thus promotes sustainable construction through the utilization of slag and recycled aggregates in pervious concrete for pavement applications. 


\section{Conclusions}

The rheological, physical, and mechanical properties of pervious concrete made with slag and recycled concrete aggregate was examined. Results showed that the increase in porosity from 10 to $20 \%$ led to a reduction in workability (slump), compressive strength, and flexural strength. It also caused an increase in void content. Experimental findings highlighted more void space (higher void content) with RCA replacement, owing to its rough, irregular surface and less solid adhered mortar. As a result, the workability and mechanical properties decreased. The incorporation of slag increased the pervious concrete slump due to its smooth surface texture. It also improved the compressive and flexural strength, owing to densification of the matrix and reduction of voids. This paper provides evidence to the ability to create a pervious concrete made with $100 \%$ RCA, $50 \%$ slag, and $10-20 \%$ porosity for pavement applications. It offers a viable and sustainable solution to global pressing issues of reducing cement-related carbon emissions while also recycling construction and demolition waste.

\section{Acknowledgements}

This work is supported by the United Arab Emirates University (UAEU) under grant number 31N322 and the School of Engineering at the American University in Dubai (AUD). The contributions of the UAEU and AUD engineers and laboratory staff are greatly appreciated.

\section{References}

[1] J. Stoner and C. Wankel, Global Sustainability Initiatives: New Models and New Approaches. USA: Information Age Publishing, 2008.

[2] Environmental Resources Limited, "Demolition Waste," Construction Press Limited, Lancaster, England, 1980.

[3] D. Kong, T. Lei, C. Ma, and J. Jiang, "Effect and mechanism of surface-coating pozzolanic materials around aggregate on properties and ITZ microstructure of recycled aggregate concrete," Construction and Building Materials, vol. 24, no. 5, pp. 701-708, 2010.

[4] C. Poon and D. Chan, "The use of recycled aggregate in concrete in Hong Kong," Resources Conservation Recycling, vol. 50, no. 3, pp. 293-305, 2007.

[5] J. Zhang, C. Shi, Y. Li, X. Pan, C. S. Poon, and Z. Xie, "Performance Enhancement of Recycled Concrete Aggregates through Carbonation," Journal of Materials in Civil Engineering, vol. 27, no. 11, 2015.

[6] T. Ikea, S. Yamane, and A. Sakamoto, "Strength of concrete containing recycled aggregate concrete," in 2nd RILEM Symp. on Demolition and Reuse of Waste, Bagneux, France, 1988.

[7] T. C. Hansen and E. Boegh, "Elasticity and drying shrinkage concrete of recycled-aggregate," ACI Journal, vol. 82 , no. 56 , pp. 648-652, 1985.

[8] A. Akbarnezhad, K. C. G. Ong, M. H. Zhang, C. T. Tam, and T. W. J. Foo, "Microwaveassisted beneficiation of recycled concrete aggregates," Construction and Building Materials, vol. 25, no. 8, pp. 3469-3479, 2011.

[9] EPA, "Reducing urban heat islands: compendium of strategies," United States Environment Protection Agency, USA, 2008.

[10] M. Gesoğlu, E. Güneyisi, G. Khoshnaw, and S. İpek, "Investigating properties of pervious concretes containing waste tire rubbers," Construction and Building Materials, vol. 63, pp. 206-213, 2014/07/30/ 2014.

[11] M.-G. Lee, Y.-S. Huang, T.-K. Chang, and C.-H. Pao, "Experimental Study of Pervious Concrete Pavement," in Emerging Technologies for Material, Design, Rehabilitation, and Inspection of Roadway Pavements, Hunan, China, 2011, p. 273.

[12] E. Ashley. (2008) Environmental and Cost Benefits of High Albedo Concrete. Concrete in focus. 2.

[13] P. Tennis, M. L. Leming, and D. J. Akers, "Pervious Concrete Pavements," Portland Cement Association and National Ready Mixed Concrete Association, Skokie, IL and Silver Spring, MD, 2004.

[14] J. Yang and G. Jiang, "Experimental study on properties of pervious concrete pavement materials," Cement and Concrete Research, vol. 33, no. 3, pp. 381-386, 2003.

[15] Y. Zaetang, V. Sata, A. Wongsa, and P. Chindaprasirt, "Properties of pervious concrete containing recycled concrete block aggregate and recycled concrete aggregate," Construction and Building Materials, vol. 111, pp. 15$21,2016$. 
[16] R. Kumar, "Influence of recycled coarse aggregate derived from construction and demolition waste (CDW) on abrasion resistance of pavement concrete," Construction and Building Materials, vol. 142, pp. 248-255, 2017.

[17] ACI Commitee 522, "Pervious Concrete: Report No. 522R-10," American Concrete Institute, Farmington Hills, Michigan, 2010.

[18] ASTM, "Standard Test Method for Slump of Hydraulic-Cement Concrete," in C143 vol. C143, ed. West Conshohocken, PA: ASTM International, 2015.

[19] ASTM, "Standard Test Method for Density and Void Content of Hardened Pervious Concrete," in C1754, ed. West Conshohocken, PA: ASTM International, 2012.

[20] F. Montes, S. Valavala, and L. M. Haselbach, "New test method for porosity measurements of Portland cement pervious concrete," Journal of ASTM International, vol. 2, no. 1, pp. 1-13, 2005.

[21] ASTM, "Standard Test Method for Compressive Strength of Cylindrical Concrete Specimens," in C39, ed. West Conshohocken, PA: ASTM, 2015.

[22] ASTM, "Standard Test Method for Flexural Strength of Concrete (Using Simple Beam with Third-Point Loading)," in C78 vol. C78, ed. West Conshohocken, PA: ASTM International, 2016.

[23] J. Newman and B. Seng Choo, Advanced Concrete Technology: Constituent Materials, Oxford, United Kingdom: Butterworth-Heinemann, 2003.

[24] J. Bijen, "Benefits of slag and fly ash," Construction and Building Materials, vol. 10, no. 5, pp. 309-314, 1996.

[25] M. Etxeberria, E. Vázquez, A. Marí, and M. Barra, "Influence of amount of recycled coarse aggregates and production process on properties of recycled aggregate concrete," Cement and Concrete Research, vol. 37, no. 5, pp. 735-742, 2007.

[26] T.-Y. Tu, Y.-Y. Chen, and C.-L. Hwang, "Properties of HPC with recycled aggregates," Cement and Concrete Research, vol. 36, no. 5, pp. 943-950, 2006. 